\title{
COVID-19: Epidemiology, Pathogenesis and Immununological Basis
}

\author{
Christèle Tchopba Nguepou*,1, Essoham Ataba ${ }^{1}$, Gnatoulma Katawa1, \\ Banfitebiyi Gambogou ${ }^{1}$, Manuel Ritter ${ }^{2}$, Simplice D. Karou ${ }^{1}$ and Yaovi Ameyapoh ${ }^{1}$
}

${ }^{1}$ Ecole Supérieure des Techniques Biologiques et Alimentaires (ESTBA)/Laboratoire de Microbiologie et de Contrôle de Qualité des Denrées Alimentaires/Unité de Recherche en Immunologie et Immunomodulation (UR2IM), Université de Lomé, Togo

2Institute of Medical Microbiology, Immunology and Parasitology (IMMIP), Medical Faculty, University of Bonn, Germany

\begin{tabular}{ll}
\hline \multicolumn{1}{c}{ Article Information } & \multicolumn{1}{c}{ Abstract } \\
\hline Received: & Background: World Health Organisation (WHO) declared COVID-19 as a Public \\
05.07 .2020 & Health Emergency of International Concern (PHEIC). This review presents the \\
Accepted: & geographical distribution of COVID-19 as of $31^{\text {st }}$ May 2020, the virus \\
03.10 .2020 & pathogenesis, the evolution of total confirmed cases and global death toll of \\
Published: & COVID-19 from 31st December 2019 to $31^{\text {st }}$ May 2020 on the 5 continents and to \\
09.10 .2020 & display the immunological basis of the disease. \\
\hline Keywords: & Methods: Literatures were found by searching online databases. The evolution of \\
Covid-19 & total confirmed cases and total confirmed deaths, every two weeks, were plotted \\
Epidemiology & using GraphPad Prism 5.1 software. \\
Pathogenesis & Results: As of 31 May 2020 at 10 :00 am, WHO reported 218 countries and \\
Immunological response & territories concerned by COVID-19 on the 5 continents, with 5934936 total \\
& confirmed cases and 367166 total deaths. SARS-CoV-2 has a spherical shape \\
& with some pleomorphism. The infection pathogenesis significantly depends on \\
& the binding between spike protein and its receptor (ACE2 principally). Clinical \\
& manifestations of the disease vary according to host immunity and range from \\
& mild to fulminant. The main mechanism for acute respiratory distress syndrome \\
& (ARDS) is the "cytokine storm". The virus employs many strategies to evade the \\
& immune response. \\
& Conclusion: COVID-19 has wreaked a lot of havoc. Investigations are still \\
& ongoing for the development of treatment and vaccines. In the meantime, \\
& measures are being taken to prevent and limit contacts. \\
\hline
\end{tabular}

DOI: $10.22401 /$ ANJS.00.4.01

*Corresponding author: chrisnono@live.com

\section{Introduction/Background}

SARS-CoV-2 emerged from December 2019 in Hubei, Wuhan, China and is responsible of an international outbreak of respiratory illness called COVID-19 by World Health Organization (WHO) [1]. Highly transmissible from human to human, SARS-CoV-2 causes a wide spectrum of clinical manifestations in patients with COVID-19 [2,3]. The full spectrum of COVID-19 ranges from mild, self-limiting respiratory tract illness to severe progressive pneumonia, multiorgan failure and death [4-7].

Four human coronaviruses (HCoVs), HCoV 229E, NL63, OC43, and HKU1 are known for their endemicity and are responsible of "non-severe acute respiratory syndrome (SARS)-like CoVs" to human. Three novel zoonotic highly pathogenic Coronaviruses, have emerged causing lethal human disease over the past two decades; they are: the SARS coronavirus (SARS-CoV now named SARS-CoV-1) discovered in November, 2002 [8], the
Middle East Respiratory Syndrome (MERS) coronavirus (MERS-CoV) in June, 2012 [9]; and SARS-CoV-2 [2,10]. Many cases of COVID-19 have been found world widely [11]. On $30^{\text {th }}$ of January 2020, COVID-19 outbreak was declared as a "Public Health Emergency of International Concern" (PHEIC) by WHO and on $11^{\text {th }}$ of March, the disease was characterized by WHO General Director as a pandemic" [12]. COVID-19 has attracted mass news media attention all around the world, more than any other disease. Scientific investigations are still ongoing about the SARS-CoV-2 worldwide, nevertheless some data are available. In view of that, this review presents the geographical distribution of COVID-19 as of $31^{\text {st }}$ May 2020, the virus pathogenesis, the evolution of total confirmed cases and global death toll of COVID-19 from $31^{\text {st }}$ December 2019 to $31^{\text {st }}$ May 2020 on the 5 continents and displays the immunological basis of the disease. 


\title{
Al-Nahrain Journal of Science
}

\author{
Special Issue: COVID-19, October 2020, pp. 1 - 12
}

\section{Methods}

\section{Protocol}

The study was carried out on March 2020. Literatures were found by searching online databases such as: Pubmed, Elsevier, Google scholar, and also WHO, European CDC and Our World in Data websites. We searched all English and French scientific publications on the epidemiology, pathogenesis, virus structure, viral replication, total confirmed cases, total confirmed deaths, immune response, immune evasion, immunological characteristics, including "nCoV"/"SARS-CoV-2"/“COVID-19". The research was done by 2 researchers independently. The sets of literature were compared and discussed with the collaboration of a senior researcher. During this phase, data from articles referenced by some authors have been inserted in our review. Endnote 7.0 (Thomson Reuters) was used to create a bibliography, to collect and manage the selected and cited articles. The process of our literature review is shown on Figure 1.

Data about the total confirmed cases and deaths on the 5 continents (Asia, Europe, America, Africa and Oceania) were collected on precise dates $\left(31^{\text {st }}\right.$ December $2019,15^{\text {th }}$ January 2020, $31^{\text {st }}$ January $2020,15^{\text {th }}$ February $2020,29^{\text {th }}$ February 2020, $15^{\text {th }}$ March 2020, $31^{\text {st }}$ March $2020,15^{\text {th }}$ April 2020, 30 ${ }^{\text {th }}$ April 2020, $15^{\text {st }}$ May 2020 and $31^{\text {st }}$ May 2020) on the website https://ourworldindata.org/ coronavirus edited by Roser et al which presents all the data collected between 6:00 am and 10:00 am by European CDC every day since $31^{\text {st }}$ December 2019.

\section{Data analysis}

Data/information collected were classified into different domains: geographical distribution of COVID-19 as of $15^{\text {th }}$ April 2020, pathogenesis of SARS-CoV-2, evolution of total confirmed cases and global death toll of Covid-19 from $31^{\text {st }}$ December 2019 to $31^{\text {st }}$ May 2020 on the 5 continents and immunological basis of COVID-19.

Numerical data about the total confirmed cases and confirmed deaths were plotted using the software GraphPad Prism 5.1.

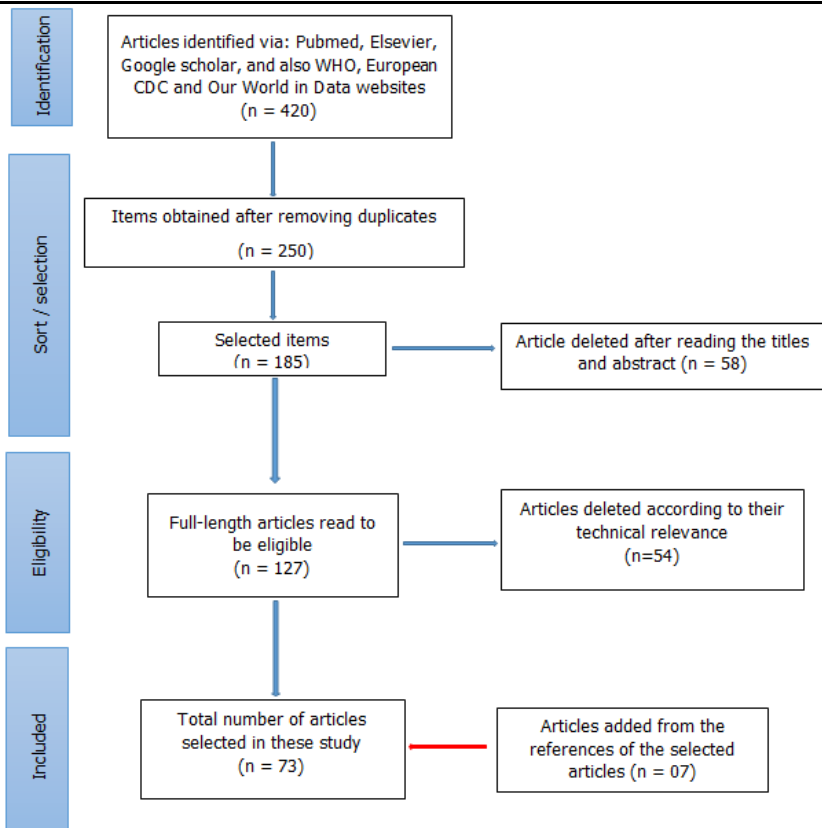

Figure 1: Process of literature review.

\section{Geographical distribution as of $31^{\text {st }}$ May 2020}

The first case of SARS-CoV-2 was reported in Hubei (Wuhan, China) and the disease has now spread almost all the countries of the world $[13,14]$. On $31^{\text {st }}$ December 2019, WHO was alerted about the rising of a pneumonia of unknown etiology in China, on $6^{\text {th }}$ January 2020 Chinese CDC activated level 2 emergency response and on $23^{\text {rd }}$ January, Wuhan was locked down to limit the virus spread [10].

As of $31^{\text {st }}$ May 2020 at 10:00 am, WHO reported 218 countries and territories concerned by COVID-19 on the 5 continents (Figure 2), with 5934936 total confirmed cases and 367166 total deaths [15]. 


\title{
Al-Nahrain Journal of Science
}

\author{
Special Issue: COVID-19, October 2020, pp. 1 - 12
}

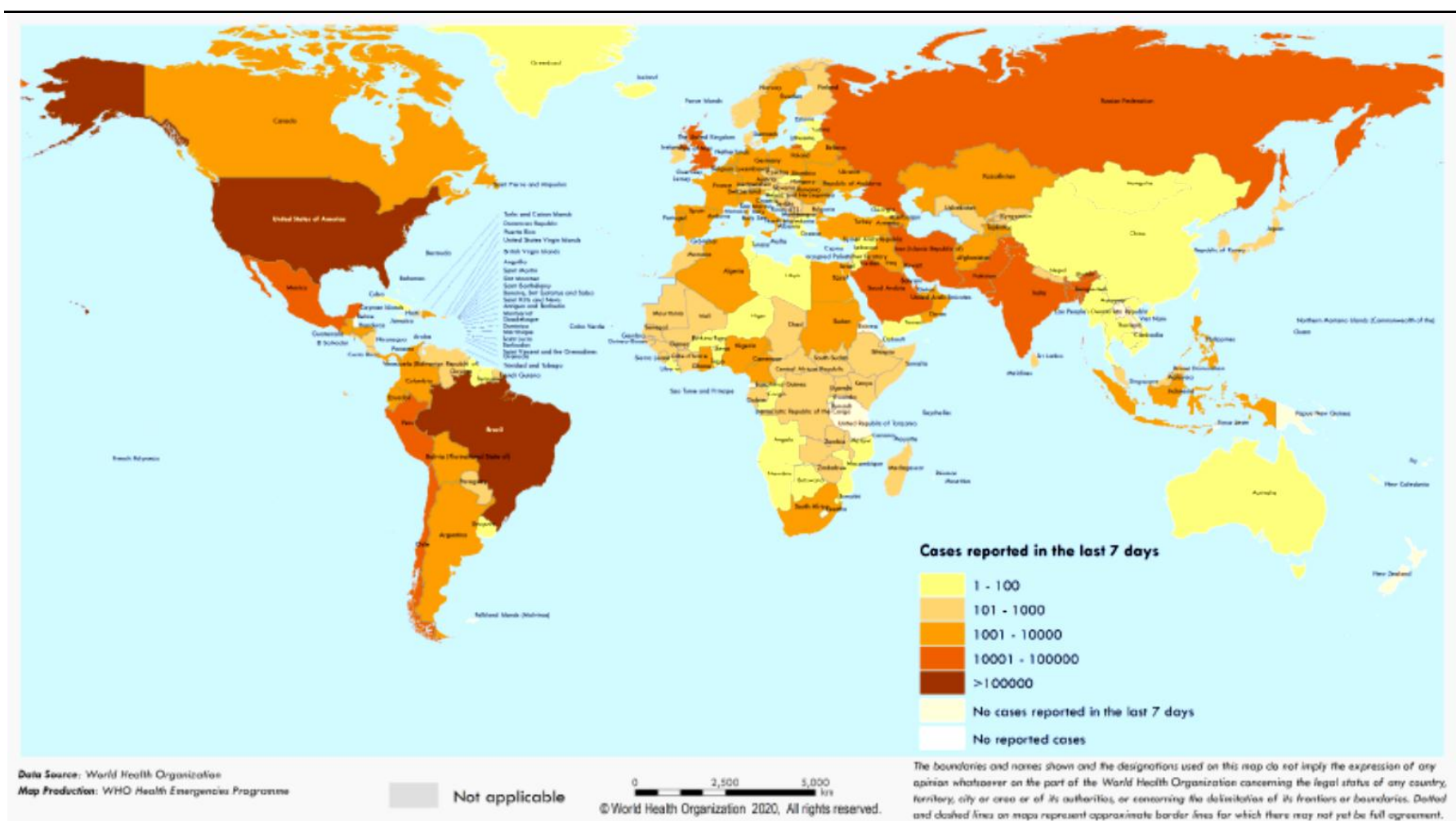

Figure 2: Global distribution of Covid-19 as of $31^{\text {th }}$ May 2020. Source: World Health Organisation [15].

\section{Pathogenesis}

SARS-CoV-2 can infect people of all ages. Men seems more affected than women $[16,17]$. No evidence has been found for COVID-19 in utero transmission from infected pregnant women to their fetuses $[18,19]$, nevertheless neonatal disease has been described [20-22].

Virus is transmitted through large droplets, and even aerosols, generated by symptomatic or asymptomatic subjects [23]. Those particles can be spread 1 to 2 meters and deposit on surfaces. People can be contaminated when inhaling the droplets/aerosols or by touching contaminated surfaces by SARS-CoV-2 and then touching nose, hand and face $[23,24]$. The virus can also be transmitted when having direct contact with a symptomatic or asymptomatic carrier. Viral load is higher in the nasal cavity than in throat with no difference between symptomatic and asymptomatic people $[14,25]$. The virus remain viable on surfaces and certain fabric or paper substrates for days in favorable atmospheric conditions, however can be successfully inactivated by using surface disinfection procedures including ethanol at $62-71 \%$, hydrogen peroxide at $0.5 \%$ or sodium hypochlorite $0.1 \%$ within 1 minute [26]. The virus mRNA has been found in the faeces, suggesting a faecal-oral transmission $[27,28]$.

\section{- Description of SARS-CoV-2}

The pathogen was firstly isolated in China on $7^{\text {th }}$ January 2020. The SARS-CoV-2 virion has the typical structure of coronaviruses. By transmission electronic imaging, the virion looks like a solar corona. The virion shape is spherical, presenting some pleomorphism. Its diameter range from 60 to $140 \mathrm{~nm}$ with quite distinctive spikes (of about 8 to $12 \mathrm{~nm}$ in length). The genetic material is a single-stranded RNA measuring 26 to $36 \mathrm{kbs}[10,29,30]$.

The genome of SARS-CoV-2 is around $38 \% \mathrm{G}+\mathrm{C}$ content $[30,31]$ with open reading frames (ORFs) (among which six are common to other coronaviruses) and some other accessory genes [10] (Figure 3). The genome possesses 14 ORFs which encode 27 proteins [32]. ORFs are located at the 5'-terminus of the genome and structural proteins (S,E,M and N) at the 3'-terminus. Also comprised on the viral genome are: $15 \mathrm{nsps}$ (nsp1 to nsp10 and nsp12 to nsp16) and 8 accessory proteins (3a, 3b, p6, 7a, 7b, 8b, $9 \mathrm{~b}$, and orf14). SARS-CoV-2 seems similar to SARS-CoV at the amino-acid level, but some notable differences exist. For example, present on SARS-CoV, the 8 a protein is absent in SARS-CoV-2, on the other hand, $8 \mathrm{~b}$ protein which is 84 amino-acids in SARS-CoV is 121 amino-acids in SARS-CoV-2; $3 \mathrm{~b}$ protein also, which is 154 aminoacids in SARS-CoV, is 22 amino-acids in SARS-CoV-2. The functionality and the pathogenesis of SARS-CoV-2 may be affected by those differences on the amino-acid content [32].

Similarities between the structural proteins of SARSCoV-2, SARS-CoV and MERS-CoV have been checked. It has been $90 \%$ genetic similarity between the proteins $\mathrm{M}$, $\mathrm{N}$ and $\mathrm{E}$ of SARS-CoV-2 and SARS-CoV, while the similarity was reduced but still high concerning the $\mathrm{S}$ protein $(76,0 \%)$. Comparing the similarity between SARS- 


\title{
Al-Nahrain Journal of Science
}

\author{
Special Issue: COVID-19, October 2020, pp. 1 - 12
}

CoV-2 and MERS-CoV, it was substantially lower for all proteins $(<50 \%)$ [33].

Structural and non-structural proteins play a specific role in viral replication [34]. The most important role belongs to $\mathrm{S}$ protein which allows viral attachment, fusion and entry in the host cell $[34,35]$.

A

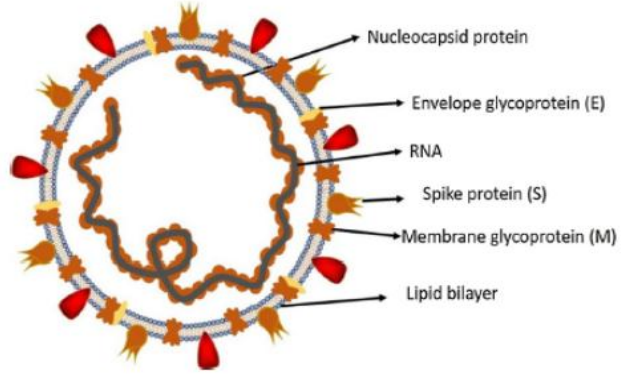

B

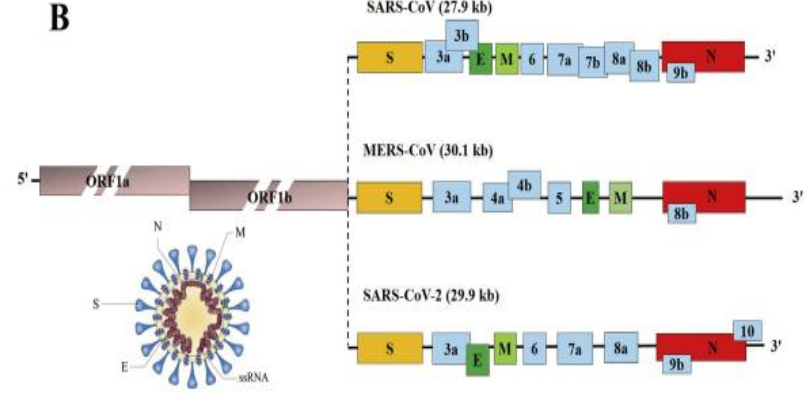

Figure 3: (A) Structure of human respiratory syndrome Coronavirus [29]. (B) Illustration of the complete genome sequences of SARS-CoV, MERS-CoV and SARS-CoV- 2. The genetic material of those viruses is a positive sense single stranded RNA (ssRNA) of $26-32 \mathrm{~kb}$ in size. The two-thirds of the genome 5'- terminal contains the genome ORF1a/b encoding polyproteins of the viral replicase transcriptase complex. ORFs located on the genome onethird encode four main structural proteins (spike (S), envelope (E), nucleocapsid (N) and membrane (M) proteins) and also several accessory proteins [36].

\section{- Receptors and target cells}

It is well known that to understand the pathogenesis of an infectious disease and design the treatment, the infection possible routes should be identified. In COVID-19, the pathogenesis of infection is highly influenced by the virus binding to the receptors of the host cell. Angiotensin converting enzyme 2 (ACE2) is the receptor target required by SARS-CoV-2 as receptor to enter cells [37, 38]. The Coronavirus trimeric S-glycoprotein binds to ACE2 on the host cell via the viral S- receptor-binding domain (RBD) [39, 40].

The tropism and the pathogenesis of Coronavirus are critically determined by host cell proteases. Numerous of those host proteases exhibited proteolysises on the spike protein; among those proteases are endosomal cathepsins, cell surface transmembrane protease serine (TMPRSS) proteases, furin, and trypsin [41].
ACE2, a metallopeptidase, has also been identified as the functional receptor for the spike glycoprotein of the human coronavirus HCoV-NL63 and SARS-CoV [37,42, 43]. According to Qi et al, investigating ACE2 expression profiles across various cell types of organs will allow to visualize the clues of the virus transmission routes and the potential pathogenesis [44]. The interaction between the SARS-CoV-2 spike protein and ACE2 is allowed through a claw like $\mathrm{N}$ - terminal peptidase domain on ACE2, made up of $\alpha$-helical lobes present on outer surface, responsible for interacting with bowl-shaped cavity on S-RBD [11]. The two main access points of the virus residues implicate in the binding process are Lys31 and Lys353 located on ACE2 at the interface of the viral receptor for $\mathrm{HCoV}$ NL63 and SARS $[45,46]$.

Comparing the distribution of ACE2 and SARS-CoV S protein in specific cells and tissues during the autopsy of four SARS patients and a control subject, He et al observed that the protein S of SARS-CoV and the ACE2 were both present in: alveolar epithelial cells, bronchial epithelial cells, bronchial serous gland epithelial cells, monocytes/macrophages, gastric parietal cells, small intestinal epithelial cells, hepatocytes, myocardial cells, distal convulated renal tubules, adrenal cortical cells, pancreatic islet cells, acidophilic cells of the parathyroid, sweath gland epithelial cells and acidophilic cells of the pituitary [47].

Sequencing single RNA of 13 human tissues (lung, liver, ileum, rectum, blood, bone narrow, skin, spleen, oesophages, colon, eye, stomach and kidney), Qi et al realized that ACE2 is expressed mainly in lung alvelolar type II cells (AT-2), liver cholangiocyte, colon colonocytes, oesophagus keratinocytes, ileum enterocytess, rectum enterocytes, stomach epithelial cells and kidney proximal cells. They also revealed some peptidases such as ANPEP, DPP4 and ENPEP, which are co-receptors of SARS-CoV-2 presenting many expression patterns similar with ACE2 [44].

Generally, the surface anchored S-protein of Coronavirus recognizes the receptor ACE2 on the host cell through its subunit $\mathrm{S} 1$; that recognition plays un key determinant role in the host specificity [48]. In the sequence of SARS-CoV-2, the receptor binding domain of protein S (S-RBD) residues directly interact with ACE2 receptor, highlighting the central role of ACE2 in SARSCoV-2 entry into the cell. Phe442, Leu472, Asn479, Asp480 and Thr487, key residues of the SARS-CoV RBD would have been transmitted to SARS-CoV-2 through natural selection and are hypothesized to involve critically in the cross-species transmission of SARS-CoV [48].

On a molecular point of view, the interaction between SARS-CoV-2 and human ACE2 is enhanced principally by the interactions between residues Gln493 and Leu455 of SARS-CoV-2 and the hospot 31 (Lys31) of ACE2. Other key residues support hotspot 31 on ACE2; they are Leu455, Phe486, Ser494 on S-protein of SARS-CoV-2. Furthermore, the stability of hospot 353 (Lys353) located 


\title{
Al-Nahrain Journal of Science
}

\author{
Special Issue: COVID-19, October 2020, pp. 1 - 12
}

on ACE2 receptor is strengthened by the residue Ser494 of SARS-CoV-2 [45].

\section{- SARS-CoV-2 replication}

Some authors reported that SARS-CoV-2 cell entry depends on both ACE2 and TMPRSS2, [49-51]. The virus uptake is increased by TMPRSS2 (Figure 4) [51].
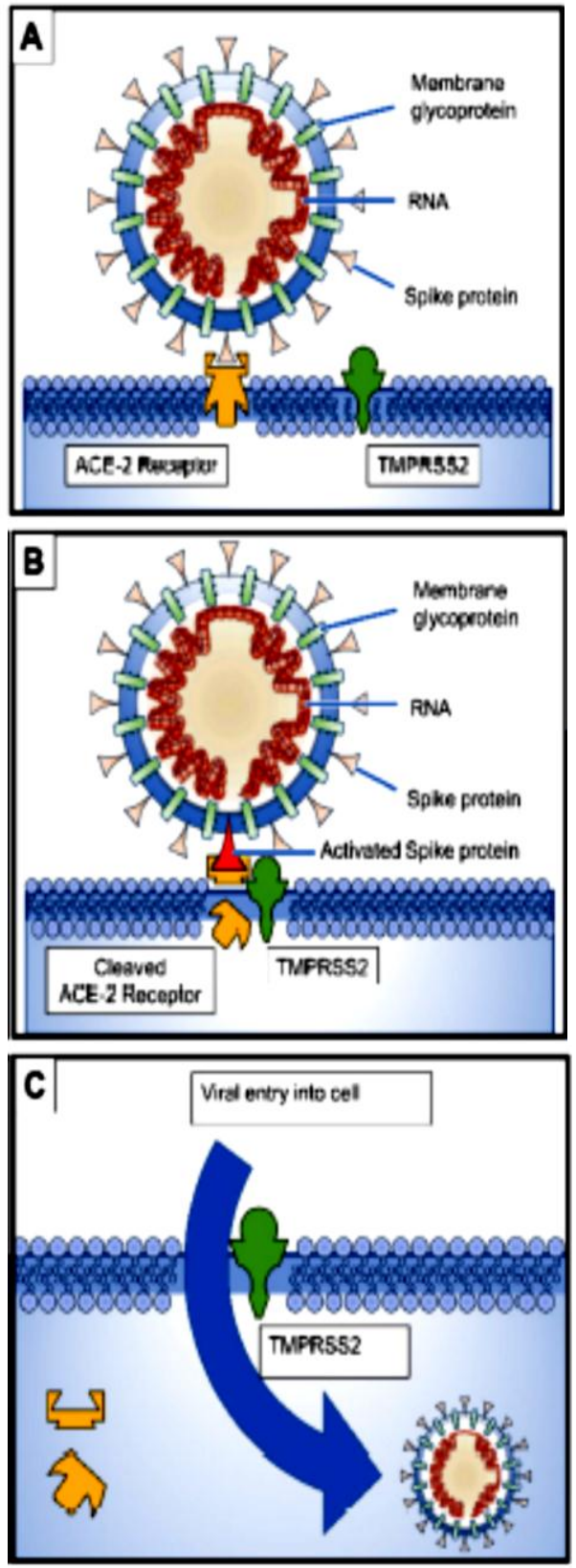

Figure 4: (A) Binding of the spike proteins of Coronavirus bind to ACE-2 receptors of the target cell; (B) TMPRSS2 binding and cleavage of the ACE-2 receptor followed by spike protein inactivation; (C) Viral entry [51].

The viral RBD of the S-protein contains 2 subunits which are necessary for endocytic pathway of the viral entry; $\mathrm{S} 1$ responsible of the binding to the host receptor and S2 subunit implicate in the fusion to the membranes of the host cell $[52,53]$. The mediators of viral fusion to cell membrane are two tandem domains of $\mathrm{S} 2$ called heptad repeats 1 and 2 (HR1 and HR2) [54]

Usually, Coronaviruses enter the target cells via two pathways: the endocytic and the non-endosomal pathway [55]. Because the capacity of SARS-CoV-2 to fuse plasma membrane is higher than that of SARS-CoV, the endocytic pathway has been extensively studied [53,56]. Indeed it has been demonstrated that SARS-CoV-2 S protein entry, precisely on $293 / \mathrm{hACE} 2$, is mainly mediated through endocytosis; on that endosomal pathway, except TMPRSS2, other molecules are essential for virus entry, such as PIKfyve, TPC2, and cathepsin [55].

SARS-CoV-2 fusion process seems identical to that of HIV-1, S1 firstly binds to the receptor on the membrane of the target cell, then the fusion peptide located at the S2 Nterminus fits into the cell membrane. Thereafter three HR1s form a trimer attaching to each other and the three HR2s separately bind on the trimer of HR1s and they form a bundle of 6-helix. Finally, virus and cell membrane so close to each other, the fusion is triggered [54].

Once the receptor and the membrane fuse together, the SARS-CoV-2 RNA is released into the host cell cytoplasm. Then the RNA is translated into ppla and pplab which are replicase polyproteins encoding nonstructural proteins and the replication-transcription complex (RTC) in double-membrane vesicle is formed. Thereafter the RTC continuously replicates and series of subgenomic RNAs are synthesized, encoding accessory and structural proteins. Virions are formed, by viral proteins and genomic RNA assemblage, in endoplasmic reticulum and Golgi, then transported via vesicles and finally fuse to the plasma membrane and are released out of the cell $[29,57]$.

Evolution of total confirmed cases and global death toll of Covid-19 from 31 ${ }^{\text {st }}$ December 2019 to $31^{\text {st }}$ May 2020 on the 5 continents

To assess the evolution of total confirmed cases and deaths on the 5 continents (Asia, Europe, America, Africa and Oceania) data were collected on precise dates, on the website https://ourworldindata.org/coronavirus edited by Roser et al which presents all the data collected between 6:00 am and 10:00 am by European CDC every day since $31^{\text {st }}$ December 2019 (Figure 5). Overall, the data follow the same trend whether it is confirmed cases of COVID-19 or the total number of deaths. It is noted that the first continent affected by the SARS-CoV-2 was Asia where the number of confirmed cases and deaths were higher until around $15^{\text {th }}$ of March, then surprisingly, high numbers of cases were noted in Europe and the trend has remained the same. Followed the case of the American continent where our graph shows an appearance of the first cases between $15^{\text {th }}$ and $29^{\text {th }}$ February and the first deaths between $29^{\text {th }}$ February and $15^{\text {th }}$ March, then quasi- 


\title{
Al-Nahrain Journal of Science
}

\author{
Special Issue: COVID-19, October 2020, pp. 1 - 12
}

exponential growth of cases and deaths until April $15^{\text {th }}$. Finally, according the data registered by the European CDC and reported by Roser et al. as of $31^{\text {st }}$ May 2020, America is the most affected continent with 2.8 millions total confirmed cases (TCC) and 161514 total confirmed deaths (TCD), followed by Europe (1.92 millions TCC and 172955 TCD), Asia (1.11 millions TCC and 30265 TCD), Africa (141632 TCC and 4071 TCD) and Oceania (8639 TCC and 132 TCD).

COVID-19 screening strategies differ from one country to another. Some countries screen suspect individuals, subjects coming from a high epidemic area or contact subjects of people already sick or diagnosed positive, while others carry out mass screening strategy.

The new strain of Coronavirus (SARS-CoV-2) is causing more deaths than the MERS-CoV and the SARSCoV. With MERS-CoV 2494 confirmed cases and 858 confirmed deaths have been registered, and for SARS-CoV 744 deaths have been registered for 8096 confirmed cases [58]. Lockdown strategies have been implemented in several countries to limit the spread of the virus pending the establishment of consistent treatment and vaccine.
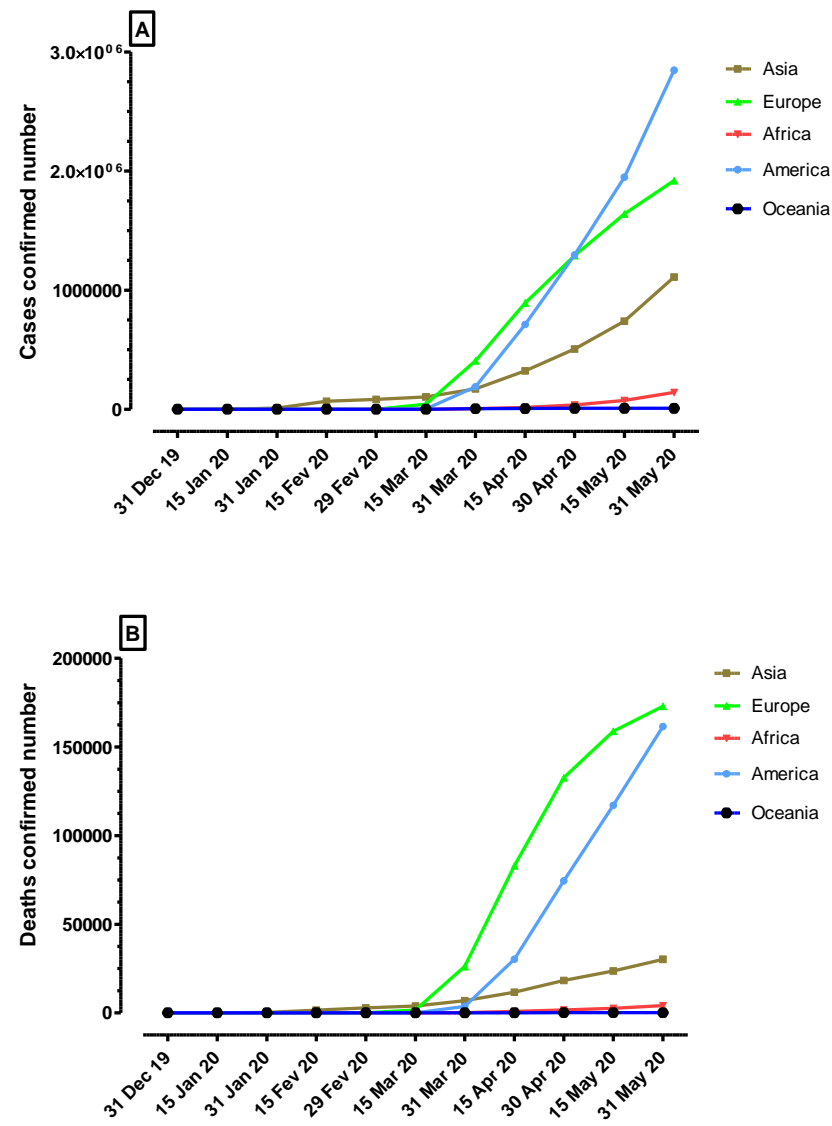

Figure 5: Evolution of total confirmed cases (A) and total confirmed deaths $(\mathbf{B})$ registered on the continents from $31^{\text {st }}$ December to $15^{\text {th }}$ April 2020. Data were collected on specific dates shown on the graphs. Data collected form https://ourworldindata.org/coronavirus' [59].

\section{Immunological Basis of COVID-19}

Since the beginning of the COVID-19 outbreak, many investigations have been done by scientific researchers and clinicians. Now, much are learned about this new disease.

Clinical manifestations SARS-CoV-2 patients can be ranged from mild, moderate to severe and rapidly progressive and fulminant disease [60]. The disease becomes frightening when severe respiratory syndrome appears; however not all people exposed to that new virus are infected and not all infected patients reach severe respiratory illness [61-63]. About $80 \%$ of COVID-19 patients can present mild or null symptoms [64, 65]. In a total of 72314 patients recorded, the Novel Coronavirus Pneumonia Emergency Response Epidemiology Team found $61.8 \%$ confirmed cases, $22.4 \%$ suspected cases, $14.6 \%$ clinical diagnosed cases (in Hubei province), and asymptomatic cases $1.2 \%$. Most of the cases confirmed were aged 30-79 years $(86.6 \%)$ and $80.9 \%$ were considered mild. A total of 1023 deaths occurred among confirmed cases for an overall case-fatality rate of $2.3 \%$ [66].

In view of the considerable impact of this epidemic worldwide (see data above), understanding the human immune responses during the SARS-CoV-2 infection is a necessity.

The virus entry in the target cell trigger host's immune response (Figure 5) and antigen-presentation cells (APC) initiate the inflammatory cascade. The APC present the SARS-CoV-2 antigen to Th1 cells ( $\mathrm{CD}^{+}{ }^{+} \mathrm{T}$ helper) and the interleukin-12 (IL-12) is released to stimulate Th1 cells again. Then Th1 cells stimulate cytotoxic Tk cells $\left(\mathrm{CD}^{+} \mathrm{T}\right.$ killer) involved in targeting and killing any cells containing foreign antigens, here SARS-CoV-2. Furthermore, B-cells involved in antigen-specific antibodes production are stimulated by Th1 cells activated Th1 cells [51].

Lymphopenia and lung damage have been reported in patients with severe cases of COVID-19, showing high levels of pro-inflammatory cytokines $[6,61]$ and level of lymphopenia correlate with the disease severity [67]. Lung damage results in acute respiratory distress syndrome (ARDS) whose the main mechanism of occurrence is the "cytokine storm". Indeed, pro-inflammatory cytokines (such as TNF- $\alpha$, IL-1 $\beta$, IL-6, IL-12, IL-33, IL-18, IFN- $\alpha$, IFN- $\gamma$, etc.) and chemokines (such as CCL2, CCL3, CCL5, CXCL8, CXCL9, CXCL10, etc.) are significantly released by effector immune cells $[6,64,68,69]$. Those cytokine initiate inflammatory responses, attacking violently the immune system, causing ARDS and death can occur [64, 70]. As the immune response is excessively activated, the number of $\mathrm{CD}^{+}$and $\mathrm{CD}^{+}$cells in the peripheral blood significantly decrease [70].

Current findings indicate that coronaviruses have the ability to evade the detection by immune cells and so they can subvert the immune response (Figure 7). This partly can explain their longer incubation period (2-11 days on average) compared to influenza viruses (1-4 days) [71]. 


\title{
Al-Nahrain Journal of Science
}

\author{
Special Issue: COVID-19, October 2020, pp. 1 - 12
}

SARS-CoV-2 immune evasion mechanism seems to be identical to those of other Betacoronavirus genus (SARS$\mathrm{CoV}$ and MERS-CoV) [58]. Some scientists reported that the survival of SARS-CoV and MERS-CoV in host cells depends on many strategies they use to subvert immune responses. Pathogen-associated moleculars (PAMPs), the evolutionarily conserved microbial structure, can be recognized by host cells via pattern recognition receptors (PRRs) [36]. SARS-CoV and MERS-CoV can avoid the detection of their dsRNA by the PRRs of the host cell; they are able to induce after fusion to host cell membrane, the production of vesicles with double membrane lacking of PRRs and then replicate in these vesicles [36, 72].

On MERS-CoV particularly, accessory protein 4a, interacting directly with dsRNA, is able to block, at the level of melanoma differentiation-associated protein 5 (MDA5), the induction of interferon [73]. It has been observed also a global down-regulation of the gene of antigen-presentation on cells infected by MERS-CoV [74]. As SARS-CoV, MERS-CoV can inhibit the IFN pathway developing an antagonistic mechanism [75,76]).

As illustrated on Figure 7, during initial immune response, Coronavirus can interfere with the steps of RNA sensing, the type I IFN production signaling pathway, and the activation of STAT1/2 downstream of IFN/IFNAR. Delaying or dampening the type I IFN responses, Coronavirus impairs the activation of adaptive immune response. The viral persistence in the cell may lead to heighten inflammatory responses and to exhaust and suppress immune response as a mechanism of regulation feedback. The poor outcome of a Coronavirus disease can be also favor by a biased Th2 type response [58].
Some study, also showed that type I interferon (interferon-alpha, IFN $\alpha$ ) induces the expression of ACE2 in nasal cells expressing both the ACE2 receptor and the TMPRSS2 co-receptor. Then, SARS-CoV-2 coronavirus takes advantage of the activation of interferon, the body's first line against a viral attack, to continue its attack on different cell types in the body [77]. Interferon-alpha (IFN $\alpha)$ stimulates the expression of the ACE2 receptor and that the higher the dose of these interferons, the more pronounced the effect. In other words, the presence on the target cells of the viral gateway is reinforced by a mechanism set up by the immune system to normally counter the viral infection [78]. The SARS-CoV-2 coronavirus therefore uses to its advantage an immune defense mechanism to spread throughout the body. In particular, the category of "cup" cells in the human nasal epithelium expressing ACE2 is the one whose genes respond most to stimulation by interferon-alpha (IFN $\alpha$ ) [79].

Considering the strategies the virus employs to evade the immune response, destroying the evasion of the immune system by SARS-CoV-2 could be helpful in the treatment of infected patients and the development of specific drug [36]. According to Raoult et al., "current evidence suggests that the most solid predictors of disease severity after infection with SARS-CoV-2 are the patient's age and the concurrence of specific co-morbidities. In contrast, there is no proof (yet) that infection by a paucisymptomatic person would result in a milder clinical course of immune competent neo-infected person". 


\section{Al-Nahrain Journal of Science}

Special Issue: COVID-19, October 2020, pp. $1-12$

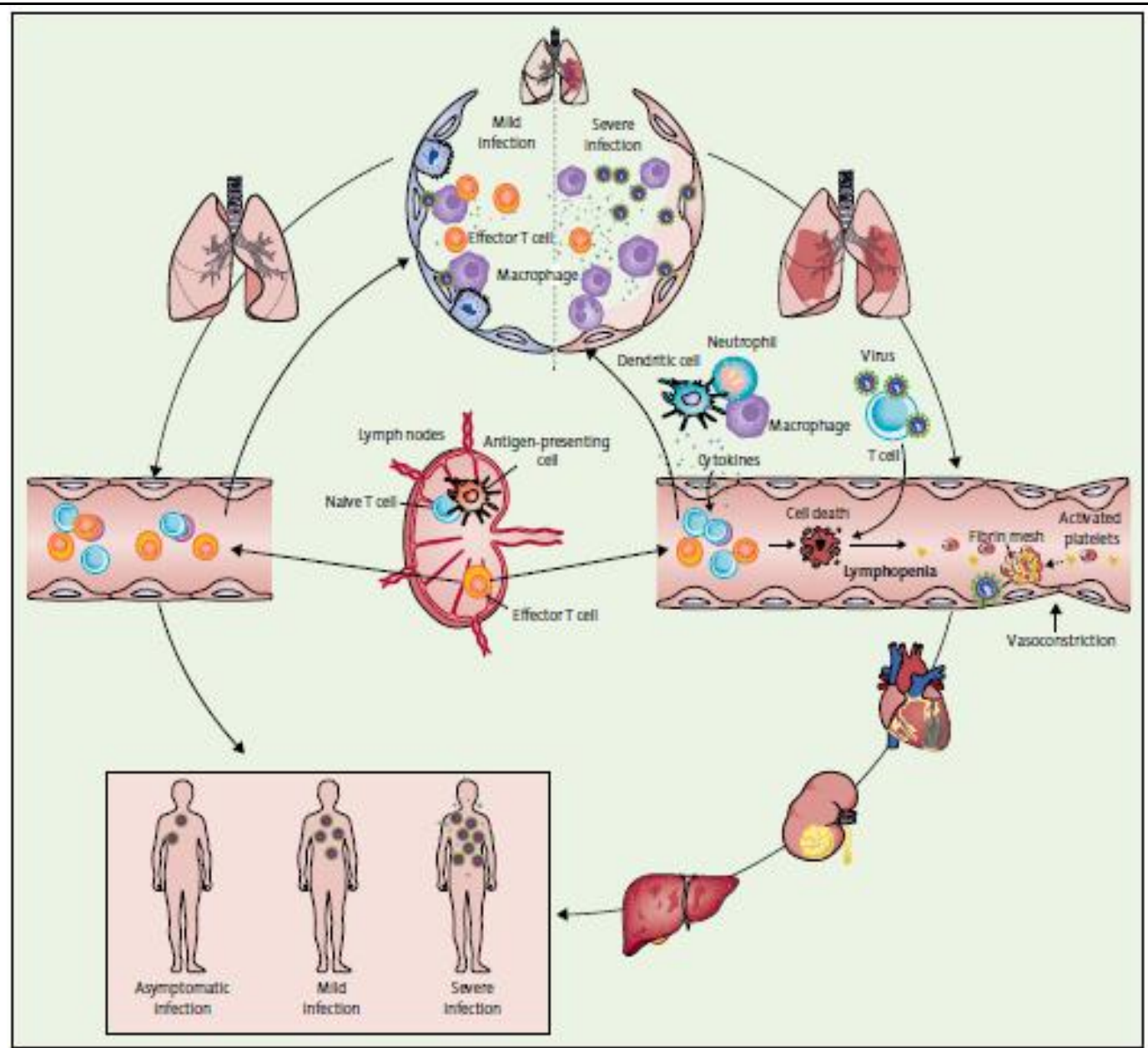

Figure 6: Mechanism of SARS-CoV-2 sepsis occurrence and outcome [80].

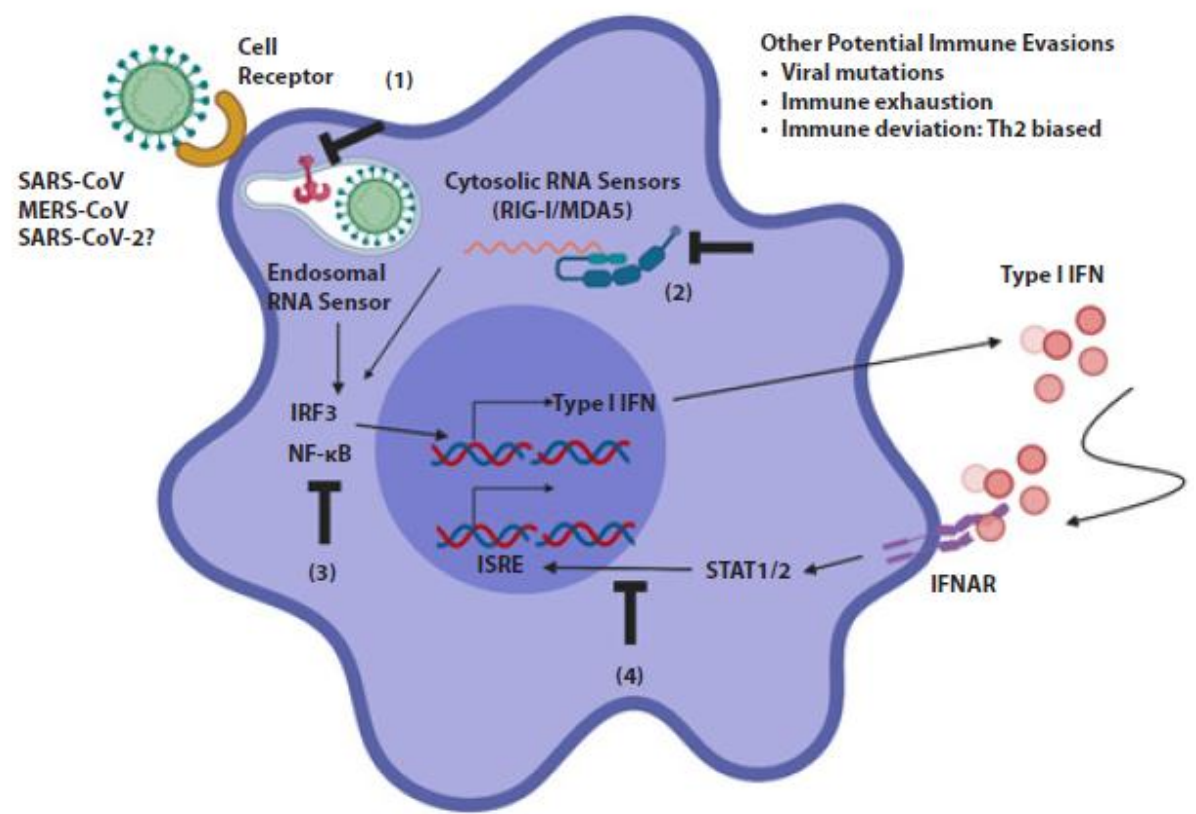

Figure 7: Mechanisms of potential evasion of immune response by human coronaviruses (SARS-CoV, MERS-CoV and SARS-CoV-2). (1 and 2): Blocking of RNA sensing, (3): Inhibition of the signaling pathway of type I IFN, (4): Inference with STAT1/2 activation downstream of IFN/IFNAR [58]. 


\title{
Al-Nahrain Journal of Science
}

\author{
Special Issue: COVID-19, October 2020, pp. 1 - 12
}

\begin{abstract}
5. Conclusion
COVID-19 is a new disease which has rapidly spread worldwide, from the Chinese province of Wuhan, via human to human contact. The SARS-CoV-2 morphology is similar to that of SARS-CoV and MERS-CoV but it remains some differences which could explain the particularity of the pathogenesis and the severity of the disease. Since $31^{\text {st }}$ December 2019, the total number of cases confirmed and confirmed deaths has increased and grown exponentially (particularly in Europe and America). Despite the fact that the infection can go unnoticed in $80 \%$ of cases, this disease scares the world because it can be devastating. This is evidenced by the millions of positive cases detected worldwide, the hundred thousands of deaths registered within 4 months and the economic means already deployed for the management of the disease. This virus, which can be easily eliminated by the body, has an arsenal of mechanisms to bypass the natural immune response. Some of the virus tragedies have been described, and investigations are still ongoing for the development of treatment and vaccines. In the meantime, measures are being taken to prevent and limit contacts.
\end{abstract}

\section{Conflict of Interest/Competing Interests}

The authors declare no conflicts of interest associated with this publication and the outcome of this work has not been influenced by any financial support.

\section{References}

1.Zhou P, Yang XL, Wang XGea. A pneumonia outbreak associated with a new coronavirus of probable bat origin. Nature 2020.

2. Raoult D, Zumla A, Locatelli F, Ippolito G, Kroemer G. Coronavirus infections: Epidemiological, clinical and immunological features and hypotheses. Cell Stress. 2020.

3. Guan WJ, Ni ZY, Hu Y, Liang WH, Ou CQ, He JX, et al. Clinical Characteristics of Coronavirus Disease 2019 in China. N Engl J Med. 2020.

4. Liu K, Fang Y, Deng Yea. Clinical characteristics of novel coronavirus cases in tertiary hospitals in Hubei Province. Chin Med J (Engl) 2020.

5. Chen N, Zhou M, Dong Xea. Epidemiological and clinical characteristics of 99 cases of 2019 novel coronavirus pneumonia in Wuhan, China: a descriptive study. Lancet 2020;395:507-13.

6. Huang C, Wang Y, Li Xea. Clinical features of patients infected with 2019 novel coronavirus in Wuhan, China. Lancet 2020;395:497-506.

7. Wang D, Hu B, Hu Cea. Clinical characteristics of 138 hospitalized patients with 2019 novel coronavirusinfected pneumonia in Wuhan, China. JAMA. 2020.

8.Update 95 - SARS: Chronology of a serial killer [Internet]. https://www.who.int/csr/don/2003 07 04/en/ (accessed: 27.04.2020). 2003.

9.Zaki AM, van Boheemen S, Bestebroer TM, Osterhaus $\mathrm{AD}$, Fouchier RA. Isolation of a novel coronavirus from a man with pneumonia in Saudi Arabia. N Engl J Med. 2012;367(19):1814-20.

10. Zheng J. SARS-CoV-2: an Emerging Coronavirus that Causes a Global Threat. Int $J$ Biol Sci. 2020;16(10):1678-85.

11. Wu JT, Leung K, Leung GM. Nowcasting and forecasting the potential domestic and international spread of the 2019-nCoV outbreak originating in Wuhan, China: a modelling study. The Lancet. 2020;395(10225):689-97.

12. Coronavirus disease (COVID-19) outbreak [Internet]. https:ww.who.int/westernpacific/emergencies/covid-19 (accessed: 27.04.2020). 2020.

13. Mackenzie JS, Smith DW. COVID-19: a novel zoonotic disease caused by a coronavirus from China: what we know and what we don't. Microbiol Aust. 2020:MA20013-MA.

14. Singhal T. A Review of Coronavirus Disease-2019 (COVID-19). Indian J Pediatr. 2020;87(4):281-6.

15. Coronavirus disease (COVID-19) Situation Report132 Data as received by WHO from national authorities by 10:00 CEST, 31 May 2020 [Internet]. 2020. Available from: https://www.who.int/docs/ default-source/coronaviruse/situation-reports/ 20200531 - covid-19-sitrep-132.pdf?sfvrsn=d9c2eaef 2.

16. Conti P, Younes A. Coronavirus COV-19/SARS-CoV2 affects women less than men: clinical response to viral infection. Journal of biological regulators and homeostatic agents. 2020;34(2).

17. Wenham C, Smith J, Morgan R. COVID-19: the gendered impacts of the outbreak. The Lancet. 2020;395(10227):846-8.

18. Karimi-Zarchi M, Neamatzadeh H, Dastgheib SA, Abbasi H, Mirjalili SR, Behforouz A, et al. Vertical Transmission of Coronavirus Disease 19 (COVID-19) from Infected Pregnant Mothers to Neonates: A Review. Fetal and Pediatric Pathology. 2020:1-5.

19. Chen H, Guo J, Wang C, Luo F, Yu X, Zhang W, et al. Clinical characteristics and intrauterine vertical transmission potential of COVID-19 infection in nine pregnant women: a retrospective review of medical records. The Lancet. 2020;395(10226):809-15.

20. Lu Q, Shi Y. Coronavirus disease (COVID-19) and neonate: What neonatologist need to know. Journal of medical virology. 2020.

21. Wang S, Guo L, Chen L, Liu W, Cao Y, Zhang J, et al. A case report of neonatal COVID-19 infection in China. Clinical infectious diseases : an official publication of the Infectious Diseases Society of America. 2020.

22. Kamali Aghdam M, Jafari N, Eftekhari K. Novel coronavirus in a 15-day-old neonate with clinical signs of sepsis, a case report. Infectious Diseases. 2020;52(6):427-9.

23. van Doremalen N, Bushmaker T, Morris DH, Holbrook MG, Gamble A, Williamson BN, et al. Aerosol and 


\section{Al-Nahrain Journal of Science}

Special Issue: COVID-19, October 2020, pp. 1 - 12

\begin{abstract}
Surface Stability of SARS-CoV-2 as Compared with SARS-CoV-1. New England Journal of Medicine. 2020;382(16):1564-7.
\end{abstract}

24. Meselson M. Droplets and Aerosols in the Transmission of SARS-CoV-2. New England Journal of Medicine. 2020.

25. Zou L, Ruan F, Huang M, Liang L, Huang H, Hong Z, et al. SARS-CoV-2 Viral Load in Upper Respiratory Specimens of Infected Patients. New England Journal of Medicine. 2020;382.

26. Kampf G, Todt D, Pfaender S, Steinmann E. Persistence of coronaviruses on inanimate surfaces and its inactivation with biocidal agents. Journal of Hospital Infection. 2020;104(3).

27. Ong SWX, Tan YK, Chia PY, Lee TH, Ng OT, Wong MSY, et al. Air, Surface Environmental, and Personal Protective Equipment Contamination by Severe Acute Respiratory Syndrome Coronavirus 2 (SARS-CoV-2) From a Symptomatic Patient. Jama. 2020.

28. Zhang T, Cui X, Zhao X, Wang J, Zheng J, Zheng G, et al. Detectable SARS-CoV-2 viral RNA in feces of three children during recovery period of COVID-19 pneumonia. 2020.

29. Shereen MA, Khan S, Kazmi A, Bashir N, Siddique R. COVID-19 infection: Origin, transmission, and characteristics of human coronaviruses. Journal of Advanced Research. 2020;24:91-8.

30. Zhu N, Zhang D, Wang W, Li X, Yang B, Song J, et al. A Novel Coronavirus from Patients with Pneumonia in China, 2019. New England Journal of Medicine. 2020;382.

31. Chan JF-W, Kok K-H, Zhu Z, Chu H, To KK-W, Yuan $\mathrm{S}$, et al. Genomic characterization of the 2019 novel human-pathogenic coronavirus isolated from a patient with atypical pneumonia after visiting Wuhan. Emerging microbes \& infections. 2020;9(1):221-36.

32. Wu A, Peng Y, Huang B, Ding X, Wang X, Niu P, et al. Genome Composition and Divergence of the Novel Coronavirus (2019-nCoV) Originating in China. Cell host \& microbe. 2020;27(3):325-8.

33. Ahmed FS, Quadeer AA, McKay RM. Preliminary Identification of Potential Vaccine Targets for the COVID-19 Coronavirus (SARS-CoV-2) Based on SARS-CoV Immunological Studies. Viruses 2020;12(3):254.

34. Chen Y, Liu Q, Guo D. Emerging coronaviruses: Genome structure, replication, and pathogenesis. 2020;92(4):418-23.

35. Beniac DR, Andonov A, Grudeski E, Booth TF. Architecture of the SARS coronavirus prefusion spike. Nature Structural \& Molecular Biology. 2006;13(8):751-2.

36. Li X, Geng M, Peng Y, Meng L, Lu S. Molecular immune pathogenesis and diagnosis of COVID-19. Journal of Pharmaceutical Analysis. 2020.

37. Li W, Moore MJ, Vasilieva N, Sui J, Wong SK, Berne $\mathrm{MA}$, et al. Angiotensin-converting enzyme 2 is a functional receptor for the SARS coronavirus. Nature. 2003;426(6965):450-4.

38. Lillie PJ, Samson A, Li A, Adams K, Capstick R, Barlow GD, et al. Novel coronavirus disease (Covid19): The first two patients in the UK with person to person transmission. Journal of Infection. 2020;80(5):578-606.

39. Jian S, Gang Y, Ke S, Yushun W, Chuming L, Hideki A, et al. Structural basis for receptor recognition by the novel coronavirus from Wuhan. 2020.

40. Li M-Y, Li L, Zhang Y, Wang X-S. Expression of the SARS-CoV-2 cell receptor gene ACE2 in a wide variety of human tissues. Infectious Diseases of Poverty. 2020;9(1):45.

41. Millet JK, Whittaker GR. Host cell proteases: Critical determinants of coronavirus tropism and pathogenesis. Virus research. 2015;202:120-34.

42. Hamming I, Timens W, Bulthuis M, Lely T, Navis G, van Goor H. Tissue distribution of ACE2 protein, the functional receptor for SARS Coronavirus. Journal of Pathology 2004;203(2):631-7.

43. ACE2 angiotensin I converting enzyme 2 [ Homo sapiens (human) ] [Internet]. https://www.ncbi.nlm. nih.gov/gene. update 5th April 2020.

44. Qi F, Qian S, Zhang S, Zhang Z. Single cell RNA sequencing of 13 human tissues identify cell types and receptors of human coronaviruses. Biochemical and Biophysical Research Communications. 2020;xx(xx).

45. Wan Y, Shang J, Graham R, Baric R, Li F. Receptor recognition by novel coronavirus from Wuhan: An analysis based on decade-long structural studies of SARS. J Virol 2020.

46. Wu KL, W., Peng G, Li F. Crystal structure of NL63 respiratory coronavirus receptorbinding domain complexed with its human receptor. Proc Natl Acad Sci U S A. 2009;106:19970-4.

47. He L, Ding Y-q, Zhang Q, Che X, He Y, Shen H, et al. Expression of elevated levels of pro-inflammatory cytokines in SARS-CoV-infected ACE2+ cells in SARS patients: Relation to the acute lung injury and pathogenesis of SARS. The Journal of pathology. 2006;210:288-97.

48. Shweta C, Yashpal SM, Shailly T. Identification of SARS-CoV-2 Cell Entry Inhibitors by Drug Repurposing Using in Silico Structure-Based Virtual Screening Approach. ChemRxiv. 2020.

49. Hoffmann M, Kleine-Weber H, Schroeder S, Kruger N, Herrler T, Erichsen S, et al. SARS-CoV-2 cell entry depends on ACE2 and TMPRSS2 and is blocked by a clinically proven Protease Inhibitor. Cell. 2020;181:110.

50. Shulla A, Heald-Sargent T, Subramanya G, Zhao J, Perlman S, Gallagher TA. Transmembrane Serine Protease Is Linked to the Severe Acute Respiratory Syndrome Coronavirus Receptor and Activates Virus Entry. J Virol. 2011;85:873-82. 


\title{
Al-Nahrain Journal of Science
}

\author{
Special Issue: COVID-19, October 2020, pp. 1 - 12
}

51. Rabi AF, Al Zoubi SM, Kasasbeh AG, Salameh MD, Al-Nasser DA. SARS-CoV-2 and Coronavirus Disease 2019: What We Know So Far. Pathogens 2020;9(231):1-14.

52. Li F. Structure, Function, and Evolution of Coronavirus Spike Proteins. Annu Rev Virol. 2016;3(1):237-61.

53. Yang N, Shen H-M. Targeting the Endocytic Pathway and Autophagy Process as a Novel Therapeutic Strategy in COVID-19. Int $J$ Biol Sci. 2020;16(10):1724-31.

54. Yu F, Du L, Ojcius DM, Pan C, Jiang S. Measures for diagnosing and treating infections by a novel coronavirus responsible for a pneumonia outbreak originating in Wuhan, China. Microbes and infection. 2020;22(2):74-9.

55. Ou X, Liu Y, Lei X, Li P, Mi D, Ren L, et al. Characterization of spike glycoprotein of SARS-CoV-2 on virus entry and its immune cross-reactivity with SARS-CoV. Nature communications. 2020;11(1):1620.

56. Xia S, Liu M, Wang C, Xu W, Lan Q, Feng S, et al. Inhibition of SARS-CoV-2 (previously 2019$\mathrm{nCoV}$ ) infection by a highly potent pan-coronavirus fusion inhibitor targeting its spike protein that harbors a high capacity to mediate membrane fusion. Cell Research. 2020;30(4):343-55.

57. Guo Y-R, Cao Q-D, Hong Z-S, Tan Y-Y, Chen S-D, Jin H-J, et al. The origin, transmission and clinical therapies on coronavirus disease 2019 (COVID-19) outbreak - an update on the status. Military Medical Research. 2020;7(1):11.

58. Prompetchara E, Ketloy C, Palaga T. Immune responses in COVID-19 and potential vaccines: Lessons learned from SARS and MERS epidemic Asian Pac J Allergy Immunol 2020.

59. Coronavirus Disease (COVID-19) - Statistics and Research [Internet]. Our World in Data https:// ourworldindata.org/coronavirus. 2020. Available from: https://ourworldindata.org/coronavirus \#what-do-weknow-about-the-risk-of-dying-from-covid-19.

60. Wu D, Wu T, Liu Q, Yang Z. The SARS-CoV-2 outbreak: What we know. International Journal of Infectious Diseases. 2020;94:44-8.

61. Shi Y, Wang Y, Shao C, Huang J, Gan J, Huang X, et al. COVID-19 infection: the perspectives on immune responses. Cell Death \& Differentiation. 2020; 27(5):1451-4.

62. Xu X-W, Wu X-X, Jiang X-G, Xu K-J, Ying L-J, Ma $\mathrm{C}-\mathrm{L}$, et al. Clinical findings in a group of patients infected with the 2019 novel coronavirus (SARS-Cov2) outside of Wuhan, China: retrospective case series. BMJ. 2020;368:m606.

63. Wang D, Hu B, Hu C, Zhu F, Liu X, Zhang J, et al. Clinical Characteristics of 138 Hospitalized Patients With 2019 Novel Coronavirus-Infected Pneumonia in Wuhan, China. Jama. 2020;323(11):1061-9.
64. Gabriella dM, Cristina S, Concetta R, Francesco R, Annalisa C. SARS-Cov-2 infection: response of human immune system and possible implications for the rapid test and treatment Int Immunopharmacol. 2020:106519.

65. Verity R, Okell LC, Dorigatti I, Winskill P, Whittaker $\mathrm{C}$, Imai $\mathrm{N}$, et al. Estimates of the severity of coronavirus disease 2019: a model-based analysis. The Lancet Infectious Diseases. 2020;20(6):669-77.

66. NCPERE T. [The epidemiological characteristics of an outbreak of 2019 novel coronavirus diseases (COVID19) in China]. Zhonghua liu xing bing xue za zhi = Zhonghua liuxingbingxue zazhi. 2020;41(2):145-51.

67. Liu J, Li S, Liu J, Liang B, Wang X, Wang H, et al. Longitudinal characteristics of lymphocyte responses and cytokine profiles in the peripheral blood of SARSCoV-2 infected patients. EBioMedicine. 2020:102763.

68. Williams AE, Chambers RC. The mercurial nature of neutrophils: still an enigma in ARDS? Am J Physiol Lung Cell Mol Physiol. 2014;306 L217eL30.

69. Cameron MJ, Bermejo-Martin, Danesh JFAea. Human immunopathogenesis of severe acute respiratory syndrome (SARS). Virus Res. 2008;133 13e9.

70. Xu Z, Shi L, Wang Yea. Pathological findings of COVID-19 associated with acute respiratory distress syndrome. Lancet Resp Med. 2020.

71. Lessler J, Reich NG, Brookmeyer R, Perl TM, Nelson KE, Cummings DA. Incubation periods of acute respiratory viral infections: a systematic review. Lancet Infect Dis. 2009;9(5):291-300.

72. Snijder EJ, van der Meer Y, Zevenhoven-Dobbe J, Onderwater JJM, van der Meulen J, Koerten HK, et al. Ultrastructure and origin of membrane vesicles associated with the severe acute respiratory syndrome coronavirus replication complex. Journal of virology. 2006;80(12):5927-40.

73. Niemeyer D, Zillinger T, Muth D, Zielecki F, Horvath G, Suliman T, et al. Middle East respiratory syndrome coronavirus accessory protein $4 \mathrm{a}$ is a type $\mathrm{I}$ interferon antagonist. J Virol. 2013;87(22):12489-95.

74. Menachery VD, Schafer A, Burnum-Johnson KE. MERS-CoV and H5N1 influenza virus antagonize antigen presentation by altering the epigenetic landscape. 2018;115(5):E1012-e21.

75. Yang Y, Ye F, Zhu N, Wang W, Deng Y, Zhao Z, et al. Middle East respiratory syndrome coronavirus ORF4b protein inhibits type I interferon production through both cytoplasmic and nuclear targets. Scientific reports. 2015;5:17554-

76. Chen X, Yang X, Zheng Y, Yang Y, Xing Y, Chen Z. SARS coronavirus papain-like protease inhibits the type I interferon signaling pathway through interaction with the STING-TRAF3-TBK1 complex. Protein Cell. 2014;5(5):369-81.

77. Pei-Hui W, Yun C. Increasing Host Cellular ReceptorAngiotensin-Converting Enzyme 2 (ACE2) Expression 


\section{Al-Nahrain Journal of Science}

Special Issue: COVID-19, October 2020, pp. $1-12$

by Coronavirus may Facilitate 2019-nCoV Infection. bioRxiv. 2020.

78. Carly G.K. Ziegler, Allon SJ, Nyquist SK, Shalek AK, Ordovas-Montanes J. SARS-CoV-2 receptor ACE2 is an interferon-stimulated gene in human airway epithelial cells and is detected in specific cell subsets across tissues. HCA Lung Biological Network. 2020.

79. Schneider WM, Chevillotte MD, Rice CM. InterferonStimulated Genes: A Complex Web of Host Defenses. Annu Rev Immunol. 2014.

80. Li H, Liu L, Zhang D, Xu J, Dai H, Tang N, et al. SARS-CoV-2 and viral sepsis: observations and hypotheses. The Lancet. 2020. 